Collection: IUFRO 7.01.00 - COST Action FP0903, Kaunas (Lithuania - 2012)

"Biological Reactions of Forest to Climate Change and Air Pollution"

Guest Editors: Elena Paoletti, Andrzej Bytnerowicz, Algirdas Augustaitis

\section{A meta-database comparison from various European Research and Monitoring Networks dedicated to forest sites}

\author{
Alina Danielewska ${ }^{(1)}$, Nicholas Clarke ${ }^{(2)}$, Janusz Olejnik ${ }^{(1-3)}$, Karin \\ Hansen ${ }^{(4)}$, Wim de Vries ${ }^{(5)}$, Lars Lundin ${ }^{(6)}$, Juha-Pekka Tuovinen ${ }^{(7)}$, \\ Richard Fischer $^{(8)}$, Marek Urbaniak ${ }^{(1)}$, Elena Paoletti ${ }^{\left({ }^{(9)}\right.}$
}

Of a wide variety of international forest research and monitoring networks, several networks are dedicated to the effects of climate change on forests, while the effects of anthropogenic pollutants on forests have been a major area for both monitoring and research for decades. The large amounts of data already obtained within existing monitoring programmes and large-scale international projects can be used to increase understanding of the state and potential of forest mitigation and adaptation to climate change in a polluted environment, and a major challenge now is to evaluate and integrate the presently available databases. We present a meta-database with the main goal to highlight available data and integrate the information about research and monitoring of selected European Research and Monitoring Networks (ERMNs). Depending on the selected ERMNs, the list of variables and the measurement units differ widely in the databases. As a result, activities related to the identification, evaluation and integration of the presently available databases are important for the scientific community. Furthermore, and equally important, the recognition of current knowledge gaps and future needed research is made easier. This analysis suggests that: ground-level ozone is under-investigated, although it is one of the pollutants of greatest concern to forests; in addition to $\mathrm{CO}_{2}$, long-term other greenhouse gasses (GHG) flux measurements should be carried out; there is still a need of improving links between monitoring of atmospheric changes and impacts on forests; research-oriented manipulative experiments in the forests are missing.

Keywords: Research and Monitoring Network, Meta-database, Forest, Monitoring

\section{Introduction}

Forest ecosystems play a major role in the water cycle, contain a large biodiversity, and are significant carbon (C) sinks and thus highly relevant in climate change mitigation. Forests play also a special function in the greenhouse gas $(\mathrm{GHG})$ balance compared to various other natural ecosystems, because of their ability to absorb and store a significant amount of carbon dioxide $\left(\mathrm{CO}_{2}\right)$ from the atmosphere (Valentini et al. 2003). Forests depend on the surrounding site conditions and climate. In the future, they are expected to face significant pressures from climate change and air pollution as well as from intensive use through larger biomass outtake for bioenergy. The effect of climate change on forests (for example through increased frequency of extreme weather events or pathogen outbreaks) is a major area of research. An equally important task is to con- tinuously monitor significant pollutants such as ozone $\left(\mathrm{O}_{3}\right)$, nitrogen $(\mathrm{N})$, acid precipitation and heavy metals. The ICP Forests, ICP Integrated Monitoring (ICPIM) and Cooperative Programme for Monitoring and Evaluation of the Long-range Transmission of Air Pollutants in Europe (EMEP) networks constitute examples of European monitoring networks which were established mainly to monitor changes in acid deposition and to correlate these with research findings. Additionally, ozone, which next to anthropogenic $\mathrm{CO}_{2}$ is a powerful GHG, is one of the main subjects of the research of several ERMNs (e.g., EMEP, ICP Forests, ICPIM, Greenhouse gas management in European land use systems (GHG-Europe), Infrastructure for Measurements of the European Carbon Cycle (IMECC) and Monitoring atmospheric composition \& climate (MACC)). A majority of the current projects in Europe are fun-
(1) Meteorology Department, Poznan University of Life Sciences, Piatkowska 94, 60-649 Poznan (Poland); (2) Norwegian Forest and Landscape Institute, P.O. Box 115, N-1431 Ås (Norway); (3) Department of Matter and Energy Fluxes, Global Change Research Center, AS CR, v.v.i. Belidla 986/4a, 60300 Brno (Czech Republic); (4) IVL Swedish Environmental Research Institute, Box 210 60, SE-100 31 Stockholm (Sweden); (5) Alterra, Wageningen University and Research Centre, P.O. Box 47, 6700 AA Wageningen (The Netherlands); (6) Department of Aquatic Sciences and Assessment, Swedish University of Agricultural Sciences, P.O. Box 7050, SE-750 07 Uppsala (Sweden); (7) Finnish Meteorological Institute, Climate Change Research, P.O. Box 503, FI-00101 Helsinki (Finland); (8) PCC of ICP Forests, Institute for World Forestry, Johann Heinrich von Thünen-Institute (vTI), Leuschnerstrasse 91 , D-21031 Hamburg (Germany); (9) Istituto per la Protezione delle Piante - CNR, v. Madonna del Piano 10, I-50019 Sesto Fiorentino (FI - Italy)

(a) Alina Danielewska (alinkadanie@poczta.onet.pl)

Received: Aug 27, 2012 - Accepted: Nov 22, 2012

Citation: Danielewska A, Clarke N, Olejnik J, Hansen K, de Vries W, Lundin L, Tuovinen J, Fischer R, Urbaniak M, Paoletti E, 2013. A meta-database comparison from various European Research and Monitoring Networks dedicated to forest sites. iForest 6: 1-9 [online 2013-01-14] URL: http://www.sisef.it/ iforest/contents?id=ifor0751-006

Communicated by: Alberto Santini

ded by the European Commission (EC) or in the framework of the United Nations Economic Commission for Europe (UNECE). Apart from the European organizations, the national environmental funding agencies (ministries of environmental protection, agriculture etc.) are fundamental.

A better understanding of the integrated effects of different anthropogenic and natural stress factors on forest ecosystem functioning is essential in order to maintain, enhance and restore multiple forest ecosystem goods and services (Fischer et al. 2011). In this context, the large amounts of data already obtained within existing monitoring programmes and large-scale international projects will be useful. A major challenge is to identify, evaluate and compare the available databases from the past research networks (like CarboEurope, NitroEurope), ongoing monitoring networks (ICP Forests, ICPIM, EMEP, LTER Europe, LIFE+ En- 
vEurope) and ongoing research networks (e.g., GHG-Europe, ICOS) and to harmonize these databases (Augustin et al. 2005, Clarke et al. 2011, Fischer et al. 2011). The description and integration of the databases on the European level will help to describe the global GHG balance on the continental scale (Dolman et al. 2008) and increase the feasibility of describing the carbon balance in Europe (Janssens et al. 2005, Ciais et al 2010, Luyssaert et al. 2010, Schulze et al. 2010).

The European Cooperation for Science and Technology (COST) programme has made a serious contribution to accomplishing the above goal. As an intergovernmental research platform established in 1971, COST is structured into particular actions, each of which has its individually defined objectives, goals and deliverables (COST 2011). In the domains of "Forests, their Products and Services" and "Earth System Science and Environmental Management", two actions which focus on monitoring of air pollution and trace gas fluxes should be mentioned FP0903 (Climate Change and Forest Mitigation and Adaptation in a Polluted Environment) and ES0804 (Advancing the Integrated Monitoring of Trace Gas Exchange between Biosphere and Atmosphere). The main objective of FP0903 is to increase the level of understanding of the present and future response of forest ecosystems to climate change in a polluted environment. Furthermore, an objective is to identify, evaluate and integrate the presently available databases, which are elaborated by the various ERMNs (Fig. 1) in order to recognize the current knowledge gaps and future emerging research needs (COST FP0903 2011).

The main aim of this paper is to present a meta-database, which is the result of the collaboration and knowledge transfer between the COST Action FP0903 countries. The elaborated tables, in the form of MS Excel spreadsheets, contain information which is freely available on the various research networks' websites, related to the effects of different stress factors such as air pollution, GHG emissions and climate change on ecosystems (in particular forest, grassland, wetland, cropland and oceans). The idea behind the meta-database is to assist in the integration of metadata from the various European networks already dealing with the effects of different stress factors on forest. While the presented meta-database includes information related to different ecosystem types (forest, grassland, wetland, cropland and oceans), this particular paper focuses especially on forest ecosystems. Despite the fact that the methodology applied in the research networks has already been described in several publications (Aubinet et al. 2000, ICP Forests 2010), the databases have not been compared and harmonized yet.

\section{Meta-database}

\section{Objective}

The main objective of the presented metadatabase is to highlight available data, compare databases and harmonize (as far as it is possible) the information from the various existing datasets. All of the selected projects are strongly concentrating on climate change and air pollution and their influence on natural ecosystems. The meta-database is freely available on the COST Action FP0903 web page (http://cost-fp0903.ipp.cnr.it/workinggroups/wg1.html). The meta-database description includes the characteristics of the

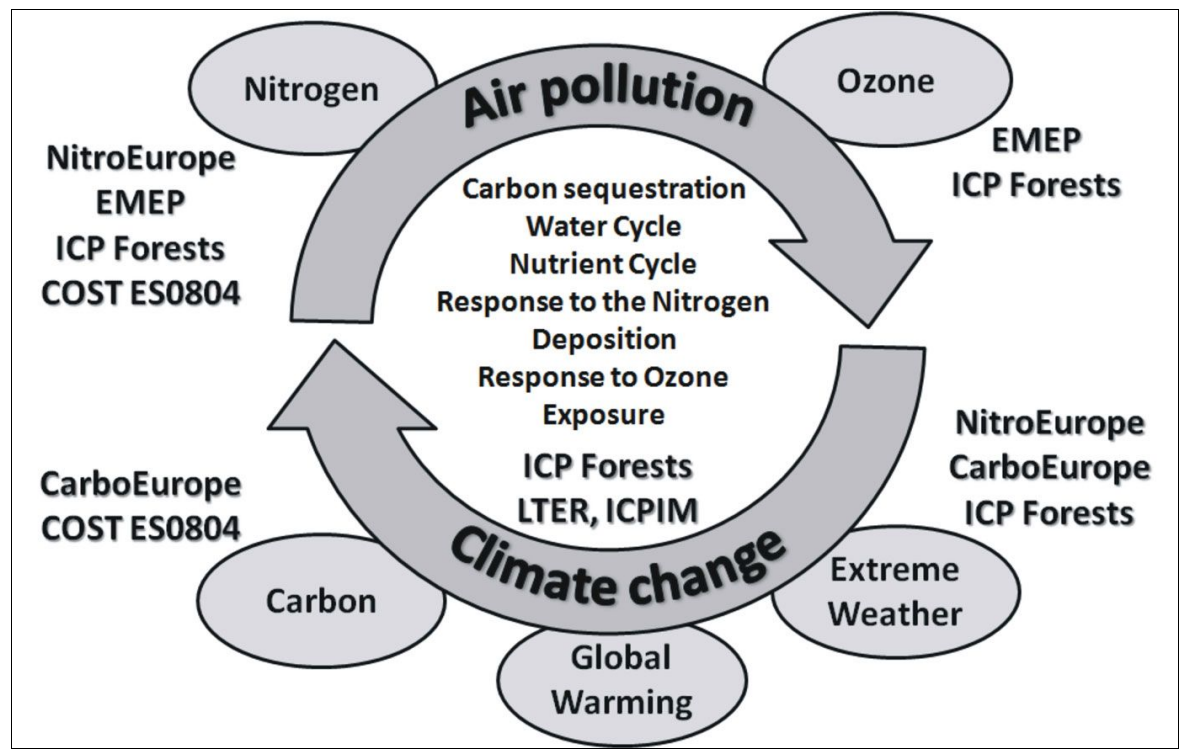

Fig. 1 - The interaction between European Research and Monitoring Networks at forests and remote sites in relation to the particular pollutant and global-scale processes (COST FP0903 2011). variables comprised in the Excel spreadsheets. The presented meta-database cannot replace existing databases, but exists merely to improve access to, and coordination between, the different datasets.

\section{Selection of research and monitoring networks}

The presented meta-database includes 15 ERMNs (Tab. 1). Project selection was based on the following criteria: pollutant type, ecosystem type, database accessibility and project status (past, ongoing, continual). For $\mathrm{C}$ (including $\mathrm{CO}_{2}$ ), the CarboEurope, GHG-Europe, IMECC, COCOS and ICOS have been selected. For N, the NitroEurope and ECLAIRE projects have been chosen. The ERMNs mentioned above provide open access to their databases, even after the termination of the projects. Furthermore, ongoing monitoring networks like ICP Forests, ICPIM, EMEP and LTER Europe have been included because of the different air pollutants and climatic parameters that are monitored and the long-term measurement time scale. What is equally important, the first two monitoring networks mentioned above are dedicated especially to forest ecosystems.

\section{Spreadsheet descriptions}

The presented meta-database is divided into 13 Excel spreadsheets. The first spreadsheet presents introductory information, including an explanation of the abbreviations used in the research. The introductory spreadsheet contains basic information about the main objective of the meta-database, the authors' affiliations and contact information. Additionally, the source of funding is acknowledged. The subsequent spreadsheets contain general site information and then information related to the particular area of interest (meteorological parameters, soil characteristics, atmospheric chemistry, fluxes of water, $\mathrm{C}$ and $\mathrm{N}$ compounds) and particular ecosystems (forest, grassland, wetland, cropland).

The first "Projects" spreadsheet describes the selected ERMNs, related to GHG monitoring, carbon and nitrogen cycle observations, air pollution and climate change research (Tab. 1). Moreover, the URLs to the project websites and databases (also the data access details) are provided. For each project the number of measurement sites is listed. Detailed information about the coordinating institution and person in charge is also given, together with the source of funding.

The "General Information" spreadsheet contains the basic characteristics of the measurement sites in each of the selected ERMNs. First, experiment allocation details (e.g., longitude, latitude, region, country) are specified. Secondly, information about the land use (site type, area, topography, form of protection) and existing infrastructure (avai- 
Tab. 1 - Basic information about the selected European Research and Monitoring Networks.

\begin{tabular}{|c|c|c|c|}
\hline Project name & Abbreviation & Web page address & Data base web page address \\
\hline $\begin{array}{l}\text { Cooperative Programme for Monitoring } \\
\text { and Evaluation of the Long-range Trans- } \\
\text { mission of Air Pollutants in Europe }\end{array}$ & EMEP & $\begin{array}{l}\text { http://tarantula.nilu.no/projects/ccc/eme } \\
\text { pdata.html and online: } \\
\text { http://ebas.nilu.no/ }\end{array}$ & $\begin{array}{l}\text { http://tarantula.nilu.no/projects/ccc } \\
\text { /emepdata.html }\end{array}$ \\
\hline $\begin{array}{l}\text { Coordination Action Carbon Observa- } \\
\text { tion System }\end{array}$ & COCOS & http://www.cocos-carbon.org/ & http://dataportal.cocos-project.org/ \\
\hline $\begin{array}{l}\text { Effects of Climate Change on Air Pollu- } \\
\text { tion Impacts and Response Strategies for } \\
\text { European Ecosystems }\end{array}$ & ECLAIRE & http://www.eclaire-fp7.eu & Not defined yet. \\
\hline $\begin{array}{l}\text { European Long-Term Ecosystem } \\
\text { Research Network }\end{array}$ & LTER & http://www.lter-europe.net & $\begin{array}{l}\text { https://secure.umweltbundesamt.at/ } \\
\text { eMORIS/jsp/common/login.jsf }\end{array}$ \\
\hline $\begin{array}{l}\text { Global Earth Observation and Monito- } \\
\text { ring of the Atmosphere }\end{array}$ & GEOMON & http://www.geomon.eu & $\begin{array}{l}\text { http://geomon.nilu.no/, ftp://ft- } \\
\text { p.nilu.no/pub/GEOmon/ }\end{array}$ \\
\hline Global Terrestrial Observing System & GTOS & http://www.fao.org/GTOS/index.html & $\begin{array}{l}\text { http://www.gosic.org/ios/GTOS_o } \\
\text { bserving_system.asp }\end{array}$ \\
\hline $\begin{array}{l}\text { Greenhouse gas management in } \\
\text { European land use systems }\end{array}$ & GHG-Europe & http://www.ghg-europe.eu/index.php & $\begin{array}{l}\text { http://www.europe- } \\
\text { fluxdata.eu/newtcdc2/ghg- } \\
\text { europe_home.aspx }\end{array}$ \\
\hline $\begin{array}{l}\text { Infrastructure for Measurements of the } \\
\text { European Carbon Cycle }\end{array}$ & IMECC & http://imecc.ipsl.jussieu.fr/ & $\begin{array}{l}\text { http://www.europe- } \\
\text { fluxdata.eu/newtcdc2/IMECC- } \\
\text { TCDC_home.aspx }\end{array}$ \\
\hline Integrated Carbon Observation System & ICOS & http://www.icos-infrastructure.eu/ & Not defined yet. \\
\hline $\begin{array}{l}\text { Integrated non- } \mathrm{CO}_{2} \text { greenhouse gas } \\
\text { Observing Systems }\end{array}$ & InGOS & http://www.ingos-infrastructure.eu/ & Not defined yet. \\
\hline $\begin{array}{l}\text { Integrated Project CarboEurope-IP } \\
\text { Assessment of the European Terrestrial } \\
\text { Carbon Balance }\end{array}$ & CarboEurope & http://www.carboeurope.org/ & $\begin{array}{l}\text { http://www.europe- } \\
\text { fluxdata.eu/imecc }\end{array}$ \\
\hline $\begin{array}{l}\text { International Cooperative Programme on } \\
\text { Integrated Monitoring of Air Pollution } \\
\text { Effects on Ecosystems }\end{array}$ & ICPIM & $\begin{array}{l}\text { http://www.environment.fi/default.asp? } \\
\text { contentid=17110\&lan=en }\end{array}$ & 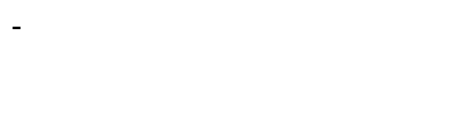 \\
\hline $\begin{array}{l}\text { International Cooperative Programme on } \\
\text { Assessment and Monitoring of Air } \\
\text { Pollution Effects on Forests }\end{array}$ & ICP Forests & http://icp-forests.net/ & $\begin{array}{l}\text { http://icp-forests.net/page/plots- } \\
\text { data }\end{array}$ \\
\hline $\begin{array}{l}\text { Monitoring atmospheric composition \& } \\
\text { climate }\end{array}$ & MACC & http://www.gmes-atmosphere.eu/ & $\begin{array}{l}\text { http://www.gmes- } \\
\text { atmosphere.eu/data/ }\end{array}$ \\
\hline $\begin{array}{l}\text { The nitrogen cycle and its influence on } \\
\text { the European greenhouse gas balance }\end{array}$ & NitroEurope & http://www.nitroeurope.eu/ & - \\
\hline
\end{tabular}

lable roads, power supply) is presented. Finally, the basic meteorological characteristics of the measurement sites (air temperature, precipitation, wind direction and wind speed) are included.

Depending on the particular ERMN's main objectives, the variables included in their databases are divided into several areas of interest including meteorological parameters, soil characteristics, atmospheric chemistry, fluxes of water, $\mathrm{C}$ and $\mathrm{N}$ compounds and additional information on e.g., the chemistry of runoff water, groundwater and surface water The distribution of variables in the selected ERMNs is presented in Fig. 2. In the first two networks (CarboEurope and NitroEurope) the highest number of variables is dedicated to meteorology and soil characteristics. A specific characteristic of these two ERMNs is also the inclusion of flux measurements of $\mathrm{C}$ and $\mathrm{N}$ compounds. The GHG-Europe and IMECC networks, as a continuation of the above projects, are concentrated on the GHG $\left(\mathrm{CO}_{2}, \mathrm{~N}_{2} \mathrm{O}\right.$ and $\left.\mathrm{CH}_{4}\right)$ balance estimation of terrestrial ecosystems in Europe with respect to natural and anthropogenic drivers like climate and land use changes (GHG-Europe 2011, IMECC 2011). In the area of atmospheric chemistry, the EMEP network includes the highest number of variables (22 in the meta-database). Furthermore, the meta-database includes 13, 17 and 14 atmospheric chemistry variables for ICP Forests, ICPIM and MACC, respectively.

The available variables in the selected ERMNs' databases are presented differently on the networks' home web sites. Variables based on direct measurements can be downloaded as site-specific values in tabular form (like in the CarboEurope network). In cases where satellites and atmospheric models are important sources of data, variables are available as regional maps and plots, differing in spatial and temporal scales (MACC 2011).

The detailed description of the meteorological variables is divided into thematic groups. The standard variables, including precipitation, air temperature, air pressure, relative humidity, wind speed and wind direction, are present in most of the selected ERMNs. Furthermore, the radiation is measured, but the particular detailed radiation components (incoming/outgoing, shortwave/ longwave radiation, global/diffuse/net radiation, photosynthetically active radiation, albedo) are dependent on the specific programme. Additionally, in ICPIM the variables related to the beginning and length of the vegetation period (VP), precipitation during VP or beginning and length of the snow cover period are described (ICPIM 2011). For some of the selected ERMNs containing micrometeorological flux data (CarboEurope, NitroEurope, GHG-Europe, IMECC, ICPIM, InGOS), the meta-database provides information on the flux measurement system and a list of micrometeorological variables related to atmospheric turbulence (like momentum flux and stability).

The most common standard for basic soil description is the Food and Agriculture Organization of the United Nations (FAO) soil classification which is applied in 6 of the se- 

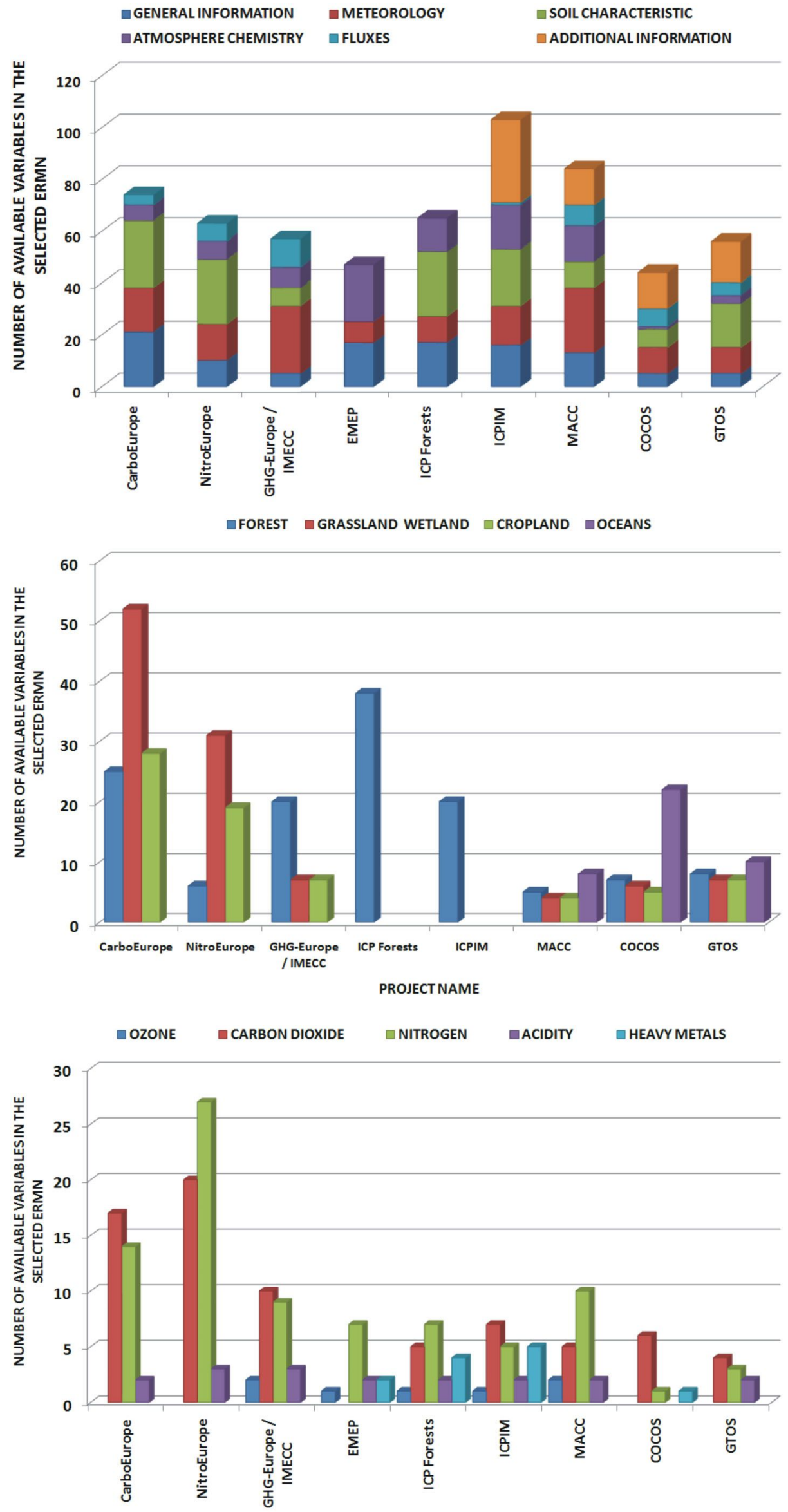

Fig. 2 - The number of variables available in the meta-database according to ERMN and area of interest.

Fig. 3 - The number of variables in the meta-database by ecosystem type and ERMN.

Fig. 4 - The number of variables in the meta-database by pollutant type and ERMN. 
lected ERMNs. The soil texture is described by the $\%$ content of sand, sandy loam, and clay loam according to the USDA Textural Triangle. In the majority of the selected ERMNs soil characteristics such as soil depth, root depth, and $\mathrm{pH}$ are given. Soil chemical variables included are total contents of $\mathrm{C}_{\text {org }}, \mathrm{N}, \mathrm{S}, \mathrm{P}, \mathrm{Ca}$, carbonate content, exchangeable contents of $\mathrm{Ca}^{2+}, \mathrm{Mg}^{2+}, \mathrm{K}^{+}, \mathrm{Na}$ and dissolved concentrations of $\mathrm{Na}, \mathrm{K}, \mathrm{Ca}$ $\mathrm{Mg}, \mathrm{Cl}, \mathrm{SO}_{4}-\mathrm{S}, \mathrm{SiO}_{2}$ and heavy metals. The soil physical properties are characterized by soil water content, conductivity, field capacity, wilting point, and moisture. The measurement units are dependent on the ERMN methodology.

The "Atmospheric chemistry" spreadsheet is divided into two parts: characteristics of air and of precipitation. Gas concentrations, such as $\mathrm{O}_{3}, \mathrm{CO}_{2}, \mathrm{H}_{2} \mathrm{O}, \mathrm{NH}_{3}, \mathrm{NH}_{4}, \mathrm{HNO}_{3}$, $\mathrm{NO}, \mathrm{NO}_{2}$, and $\mathrm{SO}_{2}$, form the most important group of variables in part one. Additionally, atmospheric aerosols, radioactive elements (MACC project - Barium 40, Caesium 137 Iodine 131, Krypton 85, Ruthenium 103 etc. in $\mathrm{Bq} \cdot \mathrm{m}^{-3}$ unit) and tracers are measured. Heavy metals such as $\mathrm{Cd}, \mathrm{Pb}, \mathrm{Cu}, \mathrm{Zn}, \mathrm{Cr}$, and $\mathrm{Ni}, \mathrm{As}$, and Persistent Organic Pollutants (POPs) are measured in both atmospheric air and precipitation. In part two of the "Atmospheric chemistry" spreadsheet throughfall/stemflow and wet/dry deposition (for $\mathrm{NH}_{4}^{+}, \mathrm{SO}_{4}{ }^{2-}, \mathrm{NO}_{3}{ }^{-}, \mathrm{Ca}, \mathrm{Mg}, \mathrm{Na}, \mathrm{K}, \mathrm{Cl}$, and $\mathrm{Hg}$ ) are included.

The data on the atmosphere-ecosystem exchange measurements are listed in the "Flux" spreadsheet. The fluxes that can be distinguished are terrestrial ecosystem fluxes, soil fluxes, and other fluxes. In the first group the $\mathrm{CO}_{2}, \mathrm{CO}, \mathrm{H}_{2} \mathrm{O}, \mathrm{CH}_{4}, \mathrm{NH}_{3}$, $\mathrm{NO}, \mathrm{N}_{2} \mathrm{O}, \mathrm{NO}_{2}$, and $\mathrm{O}_{3}$ fluxes are measured, mostly by using the eddy covariance technique as specified in the "Meteorology Measurement system" spreadsheet. The $\mathrm{CO}_{2}$ flux and autotrophic/heterotrophic respiration measurements, mostly using chamber techniques, are the most common soil variables. At the ecosystem scale, many ERMNs report Gross Primary Production (GPP), Net Primary Production (NPP), and Net Ecosystem Exchange (NEE), based on the $\mathrm{CO}_{2}$ flux measurements.

In four ERMNs (ICPIM, MACC, COCOS and GTOS), certain additional environmental information can be found related to the lake/runoff/groundwater chemistry, bird inventory, hydrobiology and glaciers. The given variables are characterized partly by a text description, partly by physical units (ICPIM 2011, MACC 2011, COCOS 2011, GTOS 2011).

The meta-database presents three separate spreadsheets taking different natural ecosystem types (forest, grassland/wetland, and cropland) into consideration. Although each of the mentioned types has numerous speci- fic variables related to it, for instance, tree parameters, grassland cutting or grazing, or cropland fertilizations, there are also variables which are common for all types. In the spreadsheets general information like site history, plant species composition, vegetation height or vegetation indexes are given. Also, particular information is given such as the single leaf/needle description (stomatal conductance, interception, wetness, LAI), through the particular tree characteristics (diameter at breast height, height, volume, age, social class), ending with the tree stand information (number of trees per unit area, phenological observations). Especially the ICP Forests database contains information about periodic events such as cuttings, fertilization, fruiting, flowering, leaf/needle damage with e.g., symptoms, causal factor, and age of damage.

ICP Forests is the project with the highest number of variables related to forest tree stand characteristics in the meta-database (Fig. 3). CarboEurope has the database with most terrestrial ecosystem-specific variables. Also, variables such as proportion of dead/green leaves and root depth are measured. Furthermore, the CarboEurope database includes factors related to management such as vegetation height after cutting as well as LAI after cutting, mineral and organic fertilization (form, amount and time period of applied fertilizers) and continuous or rotational grazing and number of animal. In CarboEurope (28 variables) and NitroEurope (19 variables) most cropland ecosystems were included. NitroEurope additionally provides information about soil profile characteristics, e.g., number of layers and their depth and biomass $\mathrm{C}$ and $\mathrm{N}$ concentrations in residues, grain and straw (CarboEurope 2011, NitroEurope 2011).

\section{Discussion}

According to FAO (2005), forests cover about $30 \%$ of the Earth's land surface, which is 3953 million ha. In conversion to area per capita this represents 0.62 ha. As forests constitute such a substantial part of the Earth's surface, it seems reasonable that an overweight of research studies are conducted in forests. According to the climatic scenarios elaborated by the Intergovernmental Panel on Climate Change, the emission of anthropogenic pollutants such as $\mathrm{CO}_{2}, \mathrm{CH}_{4}$, $\mathrm{NO}, \mathrm{N}_{2} \mathrm{O}, \mathrm{O}_{3}$ etc. will rise significantly until the year 2100 (IPCC 2001). Therefore, the reaction of forest ecosystems to these atmospheric changes is a crucial issue.

Scientific communities are interested in the mutual integration of existing international research knowledge and databases, with respect to measurement methodology, database availability and QA/QC procedures. Although each of the experimental sites has its own technical and scientific requirements, the basis for research should be as far as possible equal for all sites continentally/globally, which will enable up-scaling and comparison of results. The ICOS project constitutes an example of such a network focusing on "...building a network of standardized, long-term, high precision integrated monitoring of atmospheric greenhouse gas concentrations of $\mathrm{CO}_{2}, \mathrm{CH}_{4}, \mathrm{CO}$ and radiocarbon- $\mathrm{CO}_{2}$ to quantify the fossil fuel component, ecosystem fluxes of $\mathrm{CO}_{2}, \mathrm{H}_{2} \mathrm{O}$, and heat together with ecosystem variables..." (ICOS 2011). Furthermore, the ICOS project, which at present is in the preparatory phase, assumes that measurements will be conducted for at least 30 years. This longterm perspective is especially important to environmental research, as the changes in natural ecosystems, perhaps especially in forests, can be best described in decade-long timespans. Examples of long-term ERMNs which have been operating since the 1970 s and 80 s include ICP Forests, ICPIM and EMEP. The ongoing monitoring networks mentioned above are at present an important source of information about the natural ecosystem state, health condition and response reaction to observed climate change. By application of state-of-the-art measurement techniques such as eddy covariance, relaxed eddy accumulation, and automated chambers in various research projects and networks, the estimation of the main GHG fluxes on various spatial and temporal scales is possible. Although flux variables are reported in the meta-database, their presence is related mainly to the short-term projects (CarboEurope, NitroEurope, GHG-Europe and IMECC). Taking into consideration the above statement, it is important to enhance the ongoing monitoring networks by introducing GHG flux measurements as a standard.

The networks operate on different spatial scales. All of the selected ERMNs are significantly diversified in reference to which pollutants they treat (Fig. 4). Carbon dioxide and $\mathrm{N}$ are most researched and are therefore represented by the highest number of variables. In contrast, ozone is less investigated in the selected ERMNs.

\section{Ozone}

Ozone is an air pollutant with harmful effects on both sensitive plants and animals' respiratory systems. Additionally, this compound is a powerful GHG. Due to increased emissions of precursor compounds, the present near-surface $\mathrm{O}_{3}$ concentrations are substantially higher than the pre-industrial levels. Modern day annual average background ozone concentrations over the midlatitudes of the northern hemisphere range within approximately 20-45 ppb (Vingarzan 2004 ), which is a $100-350 \%$ increase relative to the pre-industrial age ( $\sim 10 \mathrm{ppb})$. According to the climatic scenarios this trend of 
enhanced ozone will increase in the years to come. It has been estimated that the current $\mathrm{O}_{3}$ levels decrease the biomass growth of northern hemisphere forests by 7\% (Wittig et al. 2009) and that half of the world's forests may be exposed to damaging concentrations of $>60 \mathrm{ppb}$ by 2100 (Fowler et al. 1999) The negative potential impact of ozone on trees, especially their growth, leaf/needle visible injury, productivity or biodiversity, is well documented (Matyssek \& Innes 1999, Krupa et al. 2001, Paoletti 2007). Translating this potential into impacts on world forests is still a major challenge (Serengil et al. 2011). In addition, the present standards for protection are based on the amount of ozone in the air (exposure), while the impacts arise from the amount of ozone that enters through the stomata (flux). This is why exposure and impacts appear to be decoupled in regions where other stressors limit stomatal aperture, like water stress in the Mediterranean region (Paoletti 2006)

Ozone concentration in ambient air is monitored in EMEP, ICP Forests, ICPIM, GHG-Europe, IMECC and MACC. In EMEP and ICP Forests, measurements of ozone are related to its harmful influence on the forest stand, by calculating the AOT40 index (EMEP 2011, ICP Forests 2011). AOT40 is the sum of the positive differences between the hourly mean ozone concentration and the threshold of $40 \mathrm{ppb}$, during daylight hours in a fixed growing season (Tuovinen 2000). The database of EMEP, which represents the most extensive $\mathrm{O}_{3}$ monitoring station network of these ERMNs, contains hourly $\mathrm{O}_{3}$ concentration data from 130 sites in 27 countries (for 2009 - Tørseth et al 2012). Although measurement of $\mathrm{O}_{3}$ flux is useful, the direct measurement at canopy level is more difficult than that of $\mathrm{O}_{3}$ concentrations (Cieslik et al. 2009), and for this reason these data are only available from GHG-Europe and IMECC

\section{Carbon dioxide}

The atmospheric concentration of $\mathrm{CO}_{2}$ grew from $280 \mathrm{ppm}$ in the industrial revolution period to $385 \mathrm{ppm}$ in $2010(+38 \%)$, and rose about $1.5 \mathrm{ppm}$ per year in the last decade (Sabine et al. 2004, Denman et al. 2007) This increase is related to $\mathrm{CO}_{2}$ emissions induced by fossil fuel combustion, utilization of natural gas/oil products, increasing energy consumption and land-use changes. Of all emitted $\mathrm{CO}_{2}$, only about half is returned to the atmosphere, due to sequestration of $\mathrm{C}$ in oceans and terrestrial ecosystems. Of the terrestrial ecosystems, forest ecosystems are most important with respect to $\mathrm{CO}_{2}$ assimilation from the atmosphere. Forests, including forest soils, are thus dominating the global C pools of terrestrial systems. Tropical forests are the most significant $\mathrm{C}$ pools, with boreal and middle latitude forests following. The global $\mathrm{C}$ balance in forest ecosystems has been widely described in the literature (Dixon et al. 1994, Prentice 2001, Denman et al. 2007, Luyssaert et al. 2010)

In general, forest $\mathrm{C}$, as an element, is present in the meta-database on several levels. The total organic $\mathrm{C}$ concentration in forest soils, content in roots and foliage, and the global $\mathrm{C}$ concentration in the underground biomass per unit area are variables included. The percentage $\mathrm{C}$ content in stem wood, foliage, particular shoots and leaves is measured on a single tree level (CarboEurope, NitroEurope, GHG-Europe, ICP Forests and IMECC). Upscaling the research to the stand level, the interest shifts from $\mathrm{C}$ as an element to $\mathrm{CO}_{2}$. The main area of interest is focused on measurements of forest productivity (Gross Ecosystem Production) and the net $\mathrm{CO}_{2}$ exchange rate between forest and atmosphere (Net Ecosystem Exchange), divided into tree biomass and the soil.

\section{Nitrogen}

At present, the main sources of anthropogenic nitrogen $(\mathrm{N})$ are related to $\mathrm{N}$ fertilization and $\mathrm{N}$ fixed during fossil fuel combustion (Matson et al. 2002). Modern day annual estimates of nitrogen deposition from the atmosphere over central Europe range within approximately $10-20 \mathrm{~kg} \mathrm{~N}^{-1}$ year $^{-1}$ (Matson et al. 2002, Holland et al. 2005). Nitrogen as an element is equally valuable to plants and microorganisms as it influences their growth and stimulates their productivity. Furthermore, the level of $\mathrm{N}$ affects the ecosystem species composition and biodiversity (Vitousek et al. 1997). Additionally, in the situation where nitrogen is abundant, $\mathrm{N}$ saturation can lead to $\mathrm{NO}_{3}{ }^{-}$ leaching and eutrophication (Aber et al. 1993, Gundersen et al. 1998, Fenn et al. 2003). The $\mathrm{N}$ cycle is inseparably related to the C cycle and it also stimulates plants' photosynthesis and respiration processes, which can affect the forests' ability to sequester $\mathrm{CO}_{2}$ in tree biomass (Nadelhoffer et al. 1999, De Vries et al. 2009, Schulze et al. 2010).

Nitrogen variables in the ERMNs have such points of reference as the soil level, below/aboveground biomass and single tree/ leaves/needles. In NitroEurope net $\mathrm{N}$ mineralization, nitrification, denitrification, $\mathrm{NH}_{4}^{+}$ and $\mathrm{NO}_{3}{ }^{-}$concentrations, microbial biomass and $\mathrm{NO}_{3}{ }^{-}$leaching are measured. Nitrogen is included in measurements in air $\left(\mathrm{NH}_{3}, \mathrm{NH}_{4}\right.$, $\mathrm{HNO}_{3}, \mathrm{NO}, \mathrm{NO}_{2}$ ), in precipitation (total $\mathrm{N}$, $\mathrm{NH}_{4}^{+}, \mathrm{NO}_{3}^{-}$) and in soil solutions and groundwater $\left(\mathrm{NH}_{4}^{+}\right.$and $\mathrm{NO}_{3}^{-}$concentrations).

\section{Acidity}

Sulphur dioxide $\left(\mathrm{SO}_{2}\right)$ and nitrogen dioxide $\left(\mathrm{NO}_{2}\right)$ are emitted to the atmosphere largely from anthropogenic sources such as fossil fuel combustion, transport and industry intensive development. Additionally, the variations in the concentrations of the $\mathrm{NO}_{2}$ pollutant in soil, ground water, lakes or rivers are related to the intensive agricultural production. The total $\mathrm{SO}_{2}$ emission shows a decreasing trend since 1980; in Europe and North America $-74 \%$ from 1990 to 2008 (EEA 2010, Smith et al. 2010). For 1990, the global $\mathrm{SO}_{2}$ emission was estimated at about $120 \mathrm{Tg}$. As a result of the strict controls that have been implemented in Organization for Economic Co-operation and Development (OECD) countries and the economic restructuring in Central and Eastern Europe after 1990, the $\mathrm{SO}_{2}$ emissions declined by about $20 \%$ to the year 2000 (Cofala et al. 2007). With regard to the global $\mathrm{NO}_{2}$ emissions, a decreasing trend can be observed in Europe (because of the strict emission controls in western Europe) in contrast to Asia where the emissions have increased rapidly since the 1970s (Akimoto 2003).

The removal of $\mathrm{SO}_{2}$ and $\mathrm{NO}_{2}$ compounds from the atmosphere to the natural ecosystems stems from both wet and dry deposition processes. The mechanism of acid precipitation formation is based on the oxidation of $\mathrm{SO}_{\mathrm{x}}$ and $\mathrm{NO}_{\mathrm{x}}$ in the atmosphere to acids like $\mathrm{H}_{2} \mathrm{SO}_{4}$ and $\mathrm{HNO}_{3}$, which are then deposited in precipitation (Likens \& Bormann 1974). Deposition of acidic pollutants has negative effects on forests, causing damage (discoloration, defoliation, mortality increase etc.) and decreasing forest biodiversity and productivity (Elias et al. 2009). Apart from the effects mentioned above, sulphate and inorganic $\mathrm{N}$ deposition significantly influences soil properties such as $\mathrm{pH}$, base saturation or cation exchange capacity (Diekmann \& Dupré 1997).

The variables related to acidification are included in the meta-database in several spreadsheets, depending on the area of interest (atmosphere, soil etc.). In relation to the measurements of the atmospheric air dry deposition, the following variables can be distinguished: $\mathrm{NH}_{4}^{+}, \mathrm{SO}_{4}{ }^{2-}, \mathrm{NO}_{3}^{-}, \mathrm{Ca}, \mathrm{Mg}$, $\mathrm{Na}, \mathrm{K}, \mathrm{Cl}$, and $\mathrm{Hg}$ (EMEP, ICP Forests, ICPIM, MACC, GEOMON). Measurements also include stemflow and throughfall deposition (CarboEurope, GHG-Europe, IMECC, ICP Forests and ICPIM). The research into soil acidity includes the measurement of $\mathrm{NH}_{4}^{+}$and $\mathrm{NO}_{3}{ }^{-}$concentrations in soil solution and groundwater, dissolved $\mathrm{SO}_{4}{ }^{2-}$ and heavy metals, $\mathrm{pH}$, base cations and alkalinity (ICP Forests 2011, ICPIM 2011, NitroEurope 2011).

\section{Heavy metals}

Heavy metals such as cadmium (Cd), lead $(\mathrm{Pb})$, copper $(\mathrm{Cu})$, zinc $(\mathrm{Zn})$, chromium $(\mathrm{Cr})$, nickel $(\mathrm{Ni})$ and iron $(\mathrm{Fe})$ are emitted to the 
atmosphere from the anthropogenic sources such as: coal combustion in power plants, industry (iron, steel cement production) and gasoline combustion (especially for $\mathrm{Pb}$ ). According to Pacyna et al. (2007), there has been a continuous reduction of heavy metal emissions in Europe during the last 40 years Furthermore, there is a potential for further reduction of these emissions until the year 2010 by up to about $40 \%$ for $\mathrm{Cd}, \mathrm{Cr}$, and $\mathrm{Ni}$ and about $57 \%$ for $\mathrm{Pb}$ (Pacyna et al. 2007, EMEP 2011).

The heavy metals mentioned above have negative effects on forest ecosystems, leading to different types of plant damage, like leaf discoloration, increasing tree mortality or significant decreases in tree growth and biodiversity (Menon et al. 2007, Fiala et al. 2008). Additionally, mercury $(\mathrm{Hg})$ which is also an important trace element emitted to the atmosphere, can influence not only the environment but also human health (Pacyna \& Pacyna 2002).

Depending on the forest type (coniferous, broadleaves, mixed forests), species, plant architecture (such as canopy form and visibility), and stand density, the amount of heavy metal deposition can vary. The heavy metals are mostly found in forest soils. The $\mathrm{pH}$ constitutes the key factor which determines heavy metal availability and toxicity to plants in this particular environment. Any increase in soil acidity may result in heavy metal leaching from soil (Menon et al 2007). Moreover, the trees' reactions to high concentrations of heavy metals can leave them vulnerable to more and more damage caused by different species of fungi and insects (Rademacher 2001). The following heavy metal elements are measured in the ERMNs: cadmium $(\mathrm{Cd})$, lead $(\mathrm{Pb})$, copper $(\mathrm{Cu})$, zinc $(\mathrm{Zn})$, chromium $(\mathrm{Cr})$, nickel $(\mathrm{Ni})$ and iron $(\mathrm{Fe})$. Heavy metal concentrations are measured in EMEP, LTER, ICPIM and ICP Forests

\section{Conclusions}

In the last years, the investigation and understanding of the state and potential of forest mitigation and adaptation to climate change in a polluted environment has increased significantly. Much of such research is based on a wide variety of environmental measurements carried out in the framework of various global and continental research networks. In these networks the effects of various stress factors, such as air pollution, GHG emissions and climate change on natural ecosystems have been quantified in different research projects. This paper describes a meta-database which has been created based on the major research and monitoring networks in Europe.

The main anthropogenic pollutants like $\mathrm{CO}_{2}, \mathrm{~N}$ pollutants, and heavy metals are covered fairly well by the high number of variables in the presented meta-database. However, in the case of ozone, it is ambient ozone concentrations that are often investigated, whereas fluxes of ozone which are more relevant to negative impacts on vegetation need more attention. However, the present status of ozone in the different monitoring and research networks will be improved by forthcoming projects such as "Effects of Climate Change on Air Pollution Impacts and Response Strategies for European Ecosystems" (ECLAIRE). In general, there is still a need of improving links between monitoring of atmospheric changes and impacts on forests because these two fundamental activities are carried out separately in independent ERMNs. Researchoriented manipulative experiments in the forests are limited, although they would significantly contribute to the understanding of real-world forest adaptation to the ongoing atmospheric changes.

As the climatic scenarios presented by the IPCC are not optimistic, understanding of the interactions between natural ecosystems and the atmosphere is crucial. This goal could be better attained if information about different international projects and research programmes for various ecosystems (forest, grassland, wetland, etc.), subjects (meteorology, chemistry, etc.), and ecosystem compartments (atmosphere, soil, etc.) was integrated. It is equally important to standardize the measurements, apply appropriate QA/QC procedures and improve access to and use of the different databases. By unification of the applied methodology, upscaling and comparison of the results will be possible. The presented meta-database is a first step in this direction.

Of major importance to the scientific community is the identification of current knowledge gaps and emerging research areas which are present in research projects and networks. On the basis of information included in the presented meta-database, the differences in the selected ERMNs are visible, especially in the presence of particular variables in the databases and their measurement units. There is a crucial need for harmonization and integration of research and monitoring projects and networks. One of the future possibilities for harmonization is the establishment of comprehensive and well equipped research sites, also known as $\mathrm{Su}$ persites (Fischer et al. 2011), which will be a source of detailed information about the examined ecosystem. The database established on the basis of a Supersite network will optimize the sites' geographical distribution and assure coverage of the most relevant ecosystems in Europe.

\section{Acknowledgments}

We acknowledge the COST Action FP0903 "Climate Change and Forest Mitiga- tion and Adaptation in a Polluted Environment". The meta-database was elaborated in the frame of the Short Term Scientific Mission (STSM) fellowship with the reference number COST-STSM-ECOST-STSMFP0903-011011-010860 financed by the COST Action FP0903. The STSM title is: "Establishment of a European forest monitoring meta-database". We wish to thank all scientists and experts contributing to the discussions.

\section{References}

Aber JD, Magill A, Boone R, Meillo JM, Steudler P, Bowden R (1993). Plant and soil responses to chronic nitrogen additions at the Harvard forest, Massachusetts. Ecological Application 3 (1): 156-166. - doi: 10.2307/1941798

Akimoto H (2003). Global air quality and pollution. Science 302: 1716-1719. - doi: 10.1126/ science. 1092666

Aubinet M, Grelle A, Ibrom A, Rannik U, Moncrieff J, Foken T, Kowalski AS, Martin PH, Berbigier $\mathrm{P}$, Bernhofer $\mathrm{Ch}$, Clement R, Elbers J, Granier A, Grünwald T, Morgenstern K, Pilegaard K, Rebmann C, Snijders W, Valentini R, Vesala $T$ (2000). Estimates of annual net carbon and water exchange of forest: the EUROFLUX methodology. Advances in Ecological Research 30: 113-173. - doi: 10.1016/S0065-2504(08) 60018-5

Augustin S, Evers J, Dietrich HP, Eichhorn J, Haussmann $\mathrm{T}$, Icke R, Isenberg A, Lux W, Musio M, Pretzsch H, Riek W, Rötzer T, Schultze B, Schulze A, Schröder J, Seidling W, Wellbrock N, von Wilpert K, Wolff B (2005). Concept and feasibility study for the integrated evaluation of environmental monitoring data in forests. European Journal of Forest Research 124: 251-260. - doi: 10.1007/s10342-005-00960

CarboEurope (2011). Integrated project CarboEurope-IP: assessment of the european terrestrial carbon balance. [online] URL: http://www.carboeurope.org

Ciais P, Paris JD, Marland G, Peylin P, Piao SL, Levin I, Pregger T, Scholz Y, Friedrich R, Rivier L, Houwelling S, Schulze ED, Members of the CarboEurope - IP Synthesis Team (2010). The European carbon balance. Part 1: fossil fuel emissions. Global Change Biology 16: 1395 1408. - doi: 10.1111/j.1365-2486.2009.02098.x Cieslik S, Omasa K, Paoletti E (2009). Why and how terrestrial plants exchange gases with air. Plant Biology 11: 24-34. - doi: 10.1111/j.14388677.2009.00262.x

Clarke N, Fischer R, de Vries W, Lundin L, Paoletti E, Merilä P, Matteucci G, Mirtl M, Simpson D, Vesala T (2011). Availability, accessibility, quality and comparability of monitoring data for European forests for use in air pollution and climate change science. iForest 4: 162-166. - doi: 10.3832/ifor0582-004

COCOS (2011). Coordination Action Carbon Observation System. [online] URL: http://www.cocos-carbon.org/ 
Cofala J, Amann M, Klimont Z, Kupiainen K, Höglund-Isaksson L (2007). Scenarios of global anthropogenic emissions of air pollutants and methane until 2030. Atmospheric Environment 41: 8486-8499. - doi: 10.1016/j.atmosenv.2007. 07.010

COST (2011). European cooperation in science and technology. [online] URL: http://www.cost.esf.org/

COST FP0903 (2011). European cooperation in science and technology - Action FP0903. [online] URL: http://cost-fp0903.ipp.cnr.it/

De Vries W, Solberg S, Dobbertin M, Sterba H, Laubhann D, van Oijen M, Evans C, Gundersen P, Kros J, Wamelink GWW, Reinds GJ, SuttonMA (2009). The impact of nitrogen deposition on carbon sequestration by European forests and heathlands. Forest Ecology and Management 258: 1814-1823. - doi: 10.1016/j. foreco.2009.02.034

Denman KL, Brasseur G, Chidthaisong A, Ciais P, Cox PM, Dickinson RE, Hauglustaine D, Heinze C, Holland E, Jacob D, Lohmann U, Ramachandran S, da Silva Dias PL, Wofsy SC, Zhang X (2007). Couplings between changes in the climate system and biogeochemistry. In "Climate change 2007: the physical science basis. Contribution of working group I to the fourth assessment report of the intergovernmental panel on climate change" (Solomon S, Qin D, Manning M, Chen Z, Marquis M, Averyt KB, Tignor M, Miller HL eds). Cambridge University Press, Cambridge, UK and New York, NY, USA. Diekmann M, Dupré C (1997). Acidification and eutrophication of deciduous forests in northwestern Germany demonstrated by indicator species analysis. Journal of Vegetation Science 8 855-864. - doi: 10.2307/3237030

Dixon RK, Brown S, Houghton RA, Solomon M, Trexier MC, Wisniewski J (1994). Carbon pools and flux of global forest ecosystem. Science 263: 185-190. - doi: 10.1126/science.263.5144.185

Dolman AJ, Valentini R, Freibauer A (2008). The continental-scale greenhouse gas balance of Europe. Ecological Studies 203. - doi: 10.1007/ 978-0-387-76570-9

EEA (2010). European Union emission inventory report 1990-2008 under the UNECE convention on long-range transboundary air pollution (LRTAP). EEA Technical Report No 7/2010. European Environment Agency, Copenhagen, Denmark, pp. 90.

Elias PE, Burger JA, Adams MB (2009). Acid deposition effects on forest composition and growth on the Monongahela National Forest, West Virginia. Forest Ecology and Management 258: 2175-2182. - doi: 10.1016/j.foreco.2009.05. 004

EMEP (2011). European monitoring and evaluation programme. Web site. [online] URL: http://www.emep.int

FAO (2005). Global forest resources assessment. Progress towards sustainable forest management. Food and Agriculture Organization of the United Nations, Rome, Italy.

Fenn ME, Baron JS, Allen EB, Rueth HM,
Nydick KR, Geiser L, Bowman WD, Sickman JO, Meixner T, Johnson DW, Neitlich P (2003). Ecological effects of nitrogen deposition in the Western United States. BioScience 53 (4): 404420. - doi: 10.1641/0006-3568(2003)053[0404: EEONDI]2.0.CO;2

Fiala P, Reininger D, Samek T (2008). A survey of forest pollution with heavy metals in the Natural Forest Region (NFR) Moravskoslezské Beskydy with particular attention to Jablunkov Pass. Journal of Forest Science 54 (2): 64-72. [online] URL: http://www.agriculturejournals.cz/ publicFiles/00756.pdf

Fischer R, Aas W, de Vries W, Clarke N, Cudlin P, Leaver D, Lundin L, Matteucci G, Matyssek R, Mikkelsen T, Mirtl M, Öztürk Y, Papale D, Potocic N, Simpson D, Tuovinen JP, Vesala T, Wieser G, Paoletti E (2011). Towards a transnational system of supersites for forest monitoring and research in Europe - an overview on present state and future recommendations. iForest 4 : 167-171. - doi: 10.3832/ifor0584-004

Fowler D, Cape JN, Coyle M, Flechard C, Kuylenstierna J, Hicks K, Derwent D, Johnson C, Stevenson D (1999). The global exposure of forest ecosystems to air pollutants. Water Air and Soil Pollution 116: 5-32. - doi: 10.1023/A: 1005249231882

GHG-Europe (2011). Greenhouse gas management in European land use systems. Web site. [online] URL: http://www.ghg-europe.eu/

GTOS (2011). Global terrestrial observing system. Web site. [online] URL: http:/www.fao.org/ GTOS/index. html

Gundersen P, Emmett BA, Kjøgnaas OJ, Koopmans CJ, Tietema A (1998). Impact of nitrogen deposition on nitrogen cycling in forests: a synthesis of NITREX data. Forest Ecology and Management 101: 37-55. - doi: 10.1016/S03781127(97)00124-2

Holland EA, Braswell BH Sulzman J, Lamarque JF (2005). Nitrogen deposition onto the United States and Western Europe: synthesis of observations and models. Ecological Applications 15: 38-57. - doi: 10.1890/03-5162

ICOS (2011). Integrated Carbon Observation System. Web site. [online] URL: http://www.icos-infrastructure.eu/

ICP Forests (2010). Manual on methods and criteria for harmonized sampling, assessment, monitoring and analysis of the effects of air pollution on forests. Hamburg, Germany. [online] URL: http://www.icp-forests.org/Manual.htm

ICP Forests (2011). International cooperative programme on assessment and monitoring of air pollution effects on forests. Web site. [online] URL: http://icp-forests.net/

ICPIM (2011). International cooperative programme on integrated monitoring of air pollution effects on ecosystems. Web site. [online] URL: http://www.environment.fi/default.asp?content$\mathrm{id}=17110$ \&lan $=$ en

IMECC (2011). Infrastructure for measurements of the european carbon cycle. Web site. [online] URL: http://imecc.ipsl.jussieu.fr/

IPCC (2001). Climate change 2001. The scientific basis. Contribution of working group I to the third assesment report of the Intergovernmental panel on climate change (Houghton JT, Ding Y, Nogua M, Griggs D, Vander Linden P, Maskell K eds). Cambridge University Press, New York, USA.

Janssens IA, Freibauer A, Schlamadinger B, Ceulemans R, Ciais P, Dolman AJ, Heimann M, Nabuurs GJ, Smith P, Valentini R, Schulze ED (2005). The carbon budget of terrestrial ecosystems at country-scale - a European case study. Biogeosciences 2: 15-26. - doi: 10.5194/bg-215-2005

Krupa S, McGrath MT, Andersen CP, Booker FL, Burkey KO, Chappelka AH, Chevone BI, Pell EJ, Zilinskas BA (2001). Ambient ozone and plant health. Plant Disease 85: 4-12. - doi: 10.1094/PDIS.2001.85.1.4

Likens GE, Bormann FH (1974). Acid rain: a serious regional environmental problem. Science 184: 1176-1179. - doi: 10.1126/science. 184 . 4142.1176

Luyssaert S, Ciais P, Piao SL, Schulze ED, Jung M, Zaehle S, Schelhaas MJ, Reichstein M, Churkina G, Papale D, Abril G, Beer C, Grace J, Lous Tau D, Matteucci G, Magnani F, Nabuurs GJ, Verbeeck H, Sulkava M, Van Der Werf GF, Janssens IJ, Members of the CarboEurope - IP Synthesis Team (2010). The European carbon balance. Part 3: forests. Global Change Biology 16: 1429-1450. - doi: 10.1111/j.1365-2486. 2009.02056.x

MACC (2011). Monitoring atmospheric composition \& climate. Web site. [online] URL: http://www.gmes-atmosphere.eu/

Matson P, Lohse KA, Hall SJ (2002). The globalization of nitrogen deposition: consequences for terrestrial ecosystems. Ambio 31: 113-119. - doi: 10.1579/0044-7447-31.2.113

Matyssek R, Innes JL (1999). Ozone: a risk factor for trees and forests in Europe? Water, air and soil pollution 116: 199-226. - doi: 10.1023/A: 1005267214560

Menon M, Hermle S, Günthardt-Goerg MS, Schulin R (2007). Effects of heavy metal soil pollution and acid rain on growth and water use efficiency of a young model forest ecosystem. Plant Soil 297: 171-183. - doi: 10.1007/s11104007-9331-4

Nadelhoffer KJ, Emmett BA, Gundersen P, Kjønaas OJ, Koopmans CJ, Schleppi P, Tietema A, Wright RF (1999). Nitrogen deposition makes a minor contribution to carbon sequestration in temperate forests. Nature 398: 145-148. - doi: $10.1038 / 18205$

NitroEurope (2011). The nitrogen cycle and its influence on the European greenhouse gas balance. Web site. [online] URL: http://www.nitroeurope. eu/

Pacyna EG, Pacyna JM (2002). Global emission of mercury from anthropogenic sources in 1995. Water, Air and Soil Pollution 137: 149-165. doi: 10.1023/A:1015502430561

Pacyna EG, Pacyna JM, Fudala J, StrzeleckaJastrzab E, Hlawiczka S, Panasiuk D, Nitter S, Pregger T, Pfeiffer H, Friedrich R (2007). Cur- 
rent and future emissions of selected heavy metals to the atmosphere from anthropogenic sources in Europe. Atmospheric Environment 47: 8557-8566. - doi: 10.1016/j.atmosenv.2007. 07.040

Paoletti E (2006). Impact of ozone on Mediterranean forest: a review. Environmental Pollution 144: 463-474. - doi: 10.1016/j.envpol.2005.12. 051

Paoletti E (2007). Ozone impacts on forests. CAB Reviews: Perspectives in Agriculture, Veterinary Science, Nutrition and Natural Resources 68: 13. - doi: 10.1079/PAVSNNR20072068

Prentice IC (2001). The carbon cycle and atmosphericcarbon dioxide. In: IPCC - Climate Change 2001. "The scientific basis" (Houghton JT, Ding Y, Griggs DJ, Noguer M, van der Linder PJ, Dai X, Maskell K, Johnson CA eds). Cambridge University Press, Cambridge, UK. Rademacher P (2001). Atmospheric heavy metals and forest ecosystems. Current implementation of ICP monitoring systems and contribution to risk assessment. Federal Research Centre for Forestry and Forest Products, BFH, Germany. Sabine CL, Heimann M, Artaxo P, Bakker DCE, Chen CTA, Field CB, Gruber N, Quere CL, Prinn RG, Richey JE, Lankao PR, Sathaye JA, Valentini R (2004). Current status and past trends of the global carbon cycle. In: "The global carbon cycle: Integrating humans, climate and the natural world" (Field CB, Raupach MR eds).
Island Press, Washington, USA

Schulze ED, Ciais P, Luyssaert S, Schrumpf M, Janssens IA, Thiruchittampalam B, Theloke J, Saurat M, Bringezu S, Lelieveld J, Lohila A, Rebmann C, Jung M, Bastviken D, Abril G, Grassi G, Leip A, Freibauer A, Kutsch W, Don A, Nieschulze J, Bröner A, Gash JH, Dolman AJ (2010). The European carbon balance. Part 4: Integration of carbon and other trace-gas fluxes. Global Change Biology 16: 1451-1469. - doi: 10.1111/j.1365-2486.2010.02215.x

Serengil Y, Augustaitis A, Bytnerowicz A, Grulke N, Kozovitz AR, Matyssek R, Müller-Starck G, Schaub M, Wieser G, Coskun AA, Paoletti E (2011). Adaptation of forest ecosystems to air pollution and climate change: a global assessment on research priorities. iForest 4: 44-48. doi: 10.3832/ifor0566-004

Smith SJ, van Aardenne J, Klimont Z, Andres R, Volke A, Delgado Arias S (2010). Anthropogenic sulphur dioxide emissions: 1850-2005. Atmospheric Chemistry and Physics Discussions 10: 16111-16151. - doi: 10.5194/acpd-10-61112010

Tørseth K, Aas W, Breivik K, Fjæraa AM, Fiebig M, Hjellbrekke AG, Lund Myhre C, Solberg S, Yttri KE (2012). Introduction to the european monitoring and evaluation programme (EMEP) and observed atmospheric composition change during 1972-2009. Atmospheric Chemistry and Physics Discussions 12: 1733-1820. - doi: 10.5194/acpd-12-1733-2012

Tuovinen JP (2000). Assessing vegetation exposure to ozone: properties of the AOT40 index and modifications by deposition modeling. Environmental Pollution 109: 361-371. - doi: 10.1016/S0269-7491(00)00040-3

Valentini R, Baldwin IT, Caldwell MM, Heldmaier G, Lange OL, Mooney HA, Schulze ED, Sommer U (2003). Fluxes of carbon, water and energy of european forests. Ecological Studies 163. Springer-Verlag, Berlin Heidelberg, Germany.

Vingarzan $\mathrm{R}$ (2004). A review of surface $\mathrm{O}_{3}$ background levels and trends. Atmospheric Environment 38: 3431-3442. - doi: 10.1016/j.atmosenv. 2004.03.030

Vitousek PM, Aber JD, Howarth RW, Likens GE, Matson PA, Schindler DW, Schlesinger WH, Tilman DG (1997). Human alteration of the global nitrogen cycle: sources and consequences. Ecological Applications 7 (3): 737-750. - doi: 10.1890/1051-0761(1997)007[0737:HAOTGN] 2.0.CO;2

Wittig VE, Ainsworth EA, Naidy SL, Karnosky DF, Long SP (2009). Quantifying the impact of current and future tropospheric ozone on tree biomass, growth, physiology and biochemistry: a quantitative meta-analysis. Global Change Biology 15: 396-424. - doi: 10.1111/j.1365-2486. 2008.01774.x 